\title{
Arsenic- Exposure, Mechanism of Action and Toxicity Analysis: A Prenatal View
}

\author{
Author \\ Shagun Shukla \\ Jaypee Institute of Information Technology, Noida, India \\ Email: shagun.shukla12@gmail.com
}

\begin{abstract}
Arsenic continues to poison the drinking water of thousands across the globe. Numerous studies have evaluated the carcinogenic potential of lifetime exposure and also the ill effects of prenatal exposure. Population Studies have revealed the strong correlation between the development of skin, bladder, kidney and lung cancer and arsenic exposure in endemic areas. Although the adult exposure outcomes continue to be evaluated, the prenatal exposure aspect is neglected in most studies. Our study aims to explore the co carcinogenic effect of prenatal arsenic exposure. Most experiments conducted so far in this topic utilizes models of adult exposure and very few studies have reported association of prenatal exposure to any type of carcinogenesis. This study will address the underlying mechanisms behind this association. The knowledge derived from the study can be used to develop or design early life detection markers for in utero arsenic exposure and the anomalies that may ensue.

Keywords-Arsenic, in utero, biomethylation of arsenic, tumor, carcinogenesis, prenatal.
\end{abstract}

\section{Introduction}

This Inorganic arsenic compounds are one of the most frequent pollutants found in water throughout the world specially Southern America and SouthEast Asia that have high levels of inorganic arsenic contamination in groundwater. Arsenic compounds are ecological and professional health hazard when their occurrence in the environment is augmented because of natural or anthropogenic sources. Arsenic compounds are chief components which are used mainly in the production herbicides, insecticides and fungicides. While the recommended limit of arsenic compounds in drinking water as prescribed by World Health Organization (WHO) is 0.01 ppm (WHO 2006), levels surpassing this limit have been identified in drinking water sources in areas all over the world viz. India, Vietnam, The United States, Bangladesh, Mexico and Chile.

Protracted exposure to inorganic arsenic can lead to increased risk of several forms of cancer and numerous non-cancerous ailments such as various skin diseases, chronic cough, diabetes and lethal effects on peripheral and central nervous system, liver, cardiovascular system and kidney. Arsenic is also potentially poisonous to the evolving foetus as it also easily crosses the blood placental barrier. As proposed by recent studies, arsenic exposed residents from across the world exhibit reduced foetal growth, lower birth weight, foetal mortality 
and other antagonistic pregnancy results (Ahmad et al. 2001; Hopenhayn-Rich et al. 2000; Hopenhayn et al. 2003; Kaltreider et al. 2001; Kwok et al. 2006; von Ehrenstein et al. 2006; Yang et al. 2003).Novel work conducted by the Waalkes lab has revealed numerous adverse effects of in utero arsenic contact and also has thrown light on the mechanisms relevant to the developmental toxicity of arsenic. They have established that mice exposed transplacentally to inorganic arsenates have transformed levels of manifestation of tumor suppressor genes, oncogenes and stress related genes all over their lives as adults (Waalkes et al. 2004). In humans, research in arsenic pervasive zones showed different inflammatory signalling pathways governed by $\mathrm{NF}-\kappa \mathrm{B}$ and metal regulatory transcription factors in the individuals who were prenatally exposed (Fry et al. 2007). A dose response affiliation has also been detected amid arsenic exposure and hypertension, type 2 diabetes mellitus and a range of non- cancerous end points (Lai et al. 1994; Rahman et al. 1998; Rahman et al. 1999a). Even though the vulnerability to ailments is contingent on quite a lot of variables comprising of history of alcohol intake, cigarette smoking, personal and family history of major diseases, obesity and lack of physical activity; the theory supporting parental origin of the ailment should not be abandoned. Low birth weight and gestational diabetes have been associated as strong risk factors leading to the progress of adult onset diabetes and hypertension. Some epigenetically controlled genes affecting metabolism in the adult have also been linked to onset of obesity and diabetes in individuals (Herrera et al. 2011; Martinez et al. 2012a; Slomko et al. 2012).

There are documented evidence of arsenic exposure inducing loss of DNA methylation and alterations in other epigenetic regulatory mechanisms such as histone modifications(Cronican et al. 2013) and miRNA expression both in vitro and in vivo. The abnormal methylation forms are related to malignant alteration of cells in numerous tissue categories. But these patterns are not consistent and several factors like organic samples used in the experiment, the markers used for valuation of effect of variation of the results and dietary folate consumption (Hall et al. 2007). There are abundant indications of epigenetic regulation over individual metabolism, particularly intermediate metabolism. The methylation position of these regulatory genes can be assimilated over time or programmed prenatally. The phases of primordial germ cell development and following foetal growth are for the most part susceptible to ecological abuses which may modify the epigenetic landscape of these cells.

Skin and other tissues rich in keratin are a major target organs of arsenic. It has been reported that inorganic arsenite acts as a co- carcinogen with solar ultraviolet radiation in mice when exposed lifelong as adults. However, prenatal exposure to arsenic may also have profound effects on the development and progression of several skin malignancies including squamous cell carcinoma which, according to numerous population studies, is very common in endemic areas.

For multi-stage chemical carcinogenesis, mouse skin model classifies as one of the best in vivo models. They are used to study sequential and stepwise tumor development. This model is also used to study novel techniques for the prevention of skin cancer and also the variations in genetic background and manipulation during initiation, promotion and progression of tumor.

In this, initiation and promotion stages can be specifically distinguished operationally and mechanistically. An added benefit of this model is that the tumor progress can be easily examined visually throughout the mouse's life span. At the time of termination of study or when sacrifice of animal is required, only then tissue harvest and pathological analysis are required (Abel et al. 2009).

\subsection{Arsenic}

An Arsenic is the twentieth most abundant naturally occurring element in the Earth's crust. It is chemically categorized as a metalloid, having properties of metal and non- metal. Inorganic arsenic is generally found combined with elements like oxygen, chlorine and sulphur, whereas organic 
arsenic is found in combination with carbon and hydrogen. Most arsenic compounds have no smell, taste and are white or colourless powders that do not evaporate (Giberson et al. 1976). Arsenic is ubiquitous element found in the soil, rocks, natural waters, atmosphere and organisms. It does not deteriorate and persists in the surroundings. Various forms of arsenic are arsenic $[\mathrm{As}(0)]$, arsenite [As(III)], arsenate $[\mathrm{As}(\mathrm{V})]$ and arsine Gas. The factors on which the toxicity of arsenic depends are its form (organic or inorganic), valence state, physical state, solubility and rate of absorption and elimination. Inorganic arsenic has higher toxicity as compared to organic arsenic. The rapidly absorbed forms of arsenic have high toxicity, whereas rapidly eliminated forms tend to have low toxicity (Stockert et al. 1975).paragraph.

\subsection{Occurrence and Use of Arsenic}

All Arsenic is found naturally in the earth's crust, soil and in variety of rocks, particularly in minerals and ores that have copper or lead. It exists at an average concentration of approximately $5 \mathrm{mg} / \mathrm{kg}$ of the earth's crust (WHO 2006). Natural and anthropogenic sources, both are the means of release of arsenic in the environment. Arsenic occurs as a component in more than 200 minerals, though it mainly exists as arsenopyrite and as a component in several other sulfide minerals. The arsenic enters the environment via ground water, geothermal vents and mineral ore. Local bedrocks and arsenic-rich geothermal fluids are the reason for the contamination of the water and soil. Arseniccontaining bedrock establishments are found in Bangladesh, eastern India and regions of China. Where humans are concerned in causing arsenic pollution, the cause can almost always be traced back to mining and commercial uses.

In industry, smelting process (separation of metal from rock) gives arsenic as a byproduct for many metal ores such as gold, cobalt, nickel, lead and zinc. During smelting, most of the arsenic enters the air as a fine dust as arsenic trioxide (As2O3). Earlier, arsenic was utilized in manufacturing of paints and dyes for paper, clothes and wallpaper (Stockert et al. 1975)

Inorganic arsenic was primarily used as pesticides, insecticides, herbicides, algaecides and fungicides. It is also a contaminant of moonshine whiskey (Murunga, Zawada 2007). Some organic arsenic compounds, like disodium methylarsenate (DSMA), monosodium methylarsenate (MSMA) and cacodylic acid and are also used as pesticides. Organic arsenic compounds are also the component in animal feed (NAS 1977). Many wood structures such as decks and playgrounds are treated with wood preservative which contain copper-chromatearsenate that gives greenish color to the wood. Elemental arsenic are added in small amounts to other metals to form alloys with improved properties (Albores et al. 1996). Arsenic is primarily used in lead-acid batteries for automobiles.

Currently in the electronics industry, arsenic is extensively used as modules in semiconductor devices and light-emitting diodes. Gallium arsenide is used in integral components of light-emitting diodes, semiconductor devices, photoelectric chemical cells, lasers and discrete microwave devices. Arsine gas, the most toxic arsenical is accidently encountered in metallurgical and mining processes is utilized in the microelectronics industry. Other sources of arsenic are glass manufacturing, purifying industrial gases (removal of sulfur), coalfired power plants, hardening metal alloys and desiccants used in mechanical cotton harvesting.

Arsenic has been used medicinally in various forms such as a component in induction and consolidation chemotherapy used for acute promyelocyticleukemia and other types of cancers (Hu et al. 2005; Miller et al. 2002). It is found in some traditional medications in various Asian countries (Chan 1994; Garvey et al. 2001). It is also found in some homeopathic or naturopathic therapies (Kerr and Saryan 1986). Also $1 \%$ arsenic trioxide, which is called "Fowlers solution," was historically used to treat stomatitis, leukemia and skin conditions for example eczema and psoriasis. The use of Fowler's solution resulted in skin cancer which led to remarkable decline in the use of arsenic in 
medicines (Klein et al. 2007). Arsenic is found in sea foods, specifically bivalves (scallops, oysters, mussels, clams), crustaceans (lobsters, crabs), and few cold water and bottom feeding seaweed/kelp and finfish (Rose et al. 2007)

Elevated concentration of arsenic in groundwater is also due to improperly disposed arsenical chemicals, mining, agricultural runoff and contamination from runoff from wood preservatives containing arsenic (Klein et al. 2007).

Countries where arsenic toxicity from natural source of contamination in water have been reported are. Argentina, Bangladesh, Bolivia, Canada, Chile, China, Germany (Bavaria), Ghana, Greece, Hungary, India, Japan, Mexico, Mongolia, Romania, Spain, Taiwan, United States, Vietnam (NRC 2001; ATSDR 2007).

\subsection{Routes of Exposure for Arsenic}

The World Health Organization (WHO) has laid down acceptable limit of 10 $\mu \mathrm{g} / 1$ (WHO 2006) for drinking water. Contaminated drinking water sources throughout the world have been identified with the levels that exceed the limit. The type of arsenic present in drinking water sources will differ according to its air exposure. Arsenite (arsenic III) is chiefly found in deep wells and arsenate (arsenic $\mathrm{V})$ in surface.

The major routes of arsenic entrance into the body is through inhalation and ingestion (Garvey et al. 2001). At a low level, dermal absorption of arsenic happens (Albores et al. 1996). Exposure dose is the aggregate of exposures through all routes. Main sources of inhaled arsenic come from the air releases from glass manufacturing operations, smelters, burning of fossil fuels that contain arsenic, pesticide manufacturing facilities, cotton gins, tobacco smoke (Klein et al. 2007), burning material having arsenic as a wood preservative (Aposhian et al. 2004), etc..

In the workplace, arsenic trioxide is the most common airborne arsenic which is encountered (NRC 1986). Smaller particles that are inhaled are deposited deeply in the respiratory tract. Elements that get accumulated in the upper airways gets swallowed and absorbed in gastrointestinal tract (Yip and Dart, 2001). In gastro-intestinal tract, about $95 \%$ of the consumed dose of soluble trivalent arsenic compounds is absorbed from the gastrointestinal (GI) tract (Klein et al. 2007). Arsenic also elicitate the likelihood of exposure to fetus as it can cross the placental barrier (Lugo et al. 1969). Inorganic arsenic has a half-life of 10 hours in humans (Klein et al. 2007). In liver, biomethylation of arsenic occurs and roughly $70 \%$ is excreted, primarily through urine (Klein et al. 2007).

\section{a. Distribution}

Arsenic gets absorbed by lungs or gastrointestinal tract and is extensively circulated in the body by the blood (ATSDR 2007). It is rapidly cleared by most of the tissues in the body except from keratin-rich tissues such as skin, nail, hair and in very small quantity in teeth and bones (Lansdown 1995).

\section{b. Metabolism}

After absorption of arsenic in the blood stream, it is taken up by white blood cells (WBC), red blood cells (RBC) and various cells which reduce the arsenate to arsenite (Winski and Carter 1995; Wang et al. 1996). Reduction of arsenate (As V) into arsenite (As III) is required to occur before methylation which involves glutathione (GSH) (Miller et al. 2002; Vahter et al. 1983). In the liver, some amount of arsenite (As III) is methylated by Sadenosylmethionine (SAM) which enzymatically transfers the methyl group from to methyl arsinate (MMA V) and dimethyl arsenate (DMA V) which are easily excreted (Aposhian et al. 2004; Yoshida et al. 2004).

Earlier, methylation was considered the main source of arsenic detoxification, however recent studies have shown various detoxification processes like resistance to apoptosis, antioxidant defenses or transport (Aposhian et al. 2004; Vahter 2002; Yoshida et al. 2004). Also some studies have put forth that the methylation process of inorganic arsenic instead of being a detoxification pathway, 
may be a toxification process as methylated arsenic (III) metabolites, predominantly monomethylarsonous acid (MMA III) and dimethylarsinous acid (DMA III), have potency to interact with cellular targets like DNA and proteins (Kitchin 2001). At high doses of arsenic, the methylation efficiency appears to decrease in humans. It is seen that methylated arsenic species patterns in urine are alike among siblings and parents suggesting that methylation of arsenic is genetically linked (Chung et al. 2002). Due to the increase in methylation capability of liver, increased levels of exposure to inorganic arsenic results in more accumulation in soft tissues.

\section{c. Excretion}

Arsenic in a monomethylated and dimethylated form is mainly excreted in urine via kidneys. The excreted dimethylated arsenic is roughly $50 \%$ and monomethylated is nearly $25 \%$ and the remaining is inorganic (Buchet et al. 1981). MMA V and DMA $\mathrm{V}$, the pentavalent metabolites have low toxicity as compared to arsenite or arsenate (Marafante et al. 1987). An issue of National Health and Nutrition Examination Survey 2003-2004 on urinary arsenic suggests that as the total arsenic in the urine increases, there is increase in the percentage of methylated forms and as the total arsenic levels decreases in urine, inorganic arsenic is the leading element (Caldwell et al. 2009). Arsenic level in blood may be normal due to its rapid clearance from blood, but the levels in urine may still be high (ATSDR 2007). Other routes of inorganic arsenic elimination from body are feces, sweat, skin desquamation and incorporation into nails and hair.

\subsection{Target Organs}

\section{a. Gastrointestinal and Hepatic Effects}

The gastrointestinal (GI) effects of arsenic exposure are mainly due to ingestion whereas heavy exposure through other routes may also occur.

- GI lesion seems to increase the permeability of the small blood vessels which results in loss of fluid and hypotension.
- Development of hemorrhagic gastroenteritis with bloody diarrhea.

- Mucosa and submucosa of stomach and intestine may have extensive inflammation and necrosis and may perforation of the gut wall.

- Raised liver enzyme levels may result in toxic hepatitis.

- Cirrhotic portal hypertension and noncirrhotic portal hypertension (Datta 1976); (NRC 2001); (IARC 2004); ATSDR 2007).

- Chronic high-level arsenic exposure may cause a rare form of liver cancer, hepatic angiosarcoma, (Popper et al. 1978; Zaldivar et al. 1981; ATSDR 2007).

\section{b. Renal Effects}

Renal toxicity due to arsenic exposure may lead to

- Acute tubular necrosis resulting in acute renal failure (Giberson et al. 1976).

- Chronic renal insufficiency due to cortical necrosis.

- Hypotensive shock, myoglobinuric or hemoglobinuric tubular injury, tubule cells enjury.

- Proteinuria due to glomerular damage.

\section{c. Respiratory Effects}

Inhaling large amount of arsenic compounds results in

- Irritation, inflammatory and erosive lesions of the respiratory mucosa and nasal septum perforation.

- Lung cancer is observed in pesticide workers and smelter workers (ATSDR 2007).

\section{d. Dermal Effects}

Dermal effects seen on chronic arsenic exposure may be

- Pigmentation changes and palmoplantar hyperkeratosis.

- Hyperpigmentation, hyperkeratosis and skin cancer are the most commonly occurring skin lesions.

- Benign arsenical keratoses may advance to malignancy. 
- Patchy hyperpigmentation is found on eyelids, axillae, neck, nipples extending to abdomen, chest and back.

- Hyperkeratosis due to arsenic mostly occur on palms and soles (ATSDR 2007).

\section{e. Hematopoietic and Hematologic Effects}

Arsenic intoxication may distress the hematopoietic system

- Reversible bone marrow depression may occur along with pancytopenia.

- Anaemia and leukopenia may occur which are often accompanied by mild eosinophilia and thrombocytopenia.

- The anemia may be of two typesnormocytic or macrocytic (Kyle and Pease 1965; Selzer and Ancel 1983).

\section{f. Reproductive Effects}

Arsenic being a reproductive toxicant and a teratogen gets freely transmitted across the placenta, and the concentrations in the maternal blood and cord blood are similar (Shalat et al. 1996). Due to arsenic exposure, there is increase in frequency of congenital malformations and spontaneous abortions. The incidences of malformations was found to be twice the ordinary rate and that of multiple malformations was amplified by fivefold (Nordstrom et al. 1979).

\subsection{Mechanism}

The consequences of prolonged exposure to inorganic arsenic include increased risk for various types of cancer and several non-cancerous effects such as chronic cough, skin diseases, diabetes, and toxic effects on kidney, liver, peripheral and central nervous system and cardiovascular system. Long term exposure to inorganic arsenic increases the risk of various types of cancer; including lung and prostate cancer in adult males. Because it readily crosses the blood placental barrier, arsenic is also potentially toxic to the developing fetus (Perez et al. 2003). Recent studies have suggested reduced fetal growth, lower birth weight, fetal mortality and other adverse pregnancy outcomes in arsenic exposed populations from across the globe (Ahmad et al.
2001; Hopenhayn-Rich et al. 2000; Hopenhayn et al. 2003; Kaltreider et al. 2001; Kwok et al. 2006; von Ehrenstein et al. 2006; Yang et al. 2003). Arsenic targets a vast range of enzyme reactions affecting almost all organ systems, but the most profound endpoint is dermal effects (ATSDR 2007). Skin and lung have strongest association between cancer and chronic arsenic exposure as compared to Liver (angiosarcoma), kidney, and other cancers (IARC 2004; NRC 2001).

Arsenic being a small molecule can easily enter in the cell and can result in cell injury and death by various mechanisms. Arsenic toxicity is well understood by its interference in cellular respiration by the following mechanisms:

- Arsenic, especially As (III) disrupts the enzymes containing sulfhydryl by binding with the sulfhydryl groups. Due to the critical enzyme effects, there might be decrease in oxidative phosphorylation, inhibiting the pyruvate oxidation path and the tricarboxylic acid cycle and reduced gluconeogenesis

- Replacement of As (V) in place of phosphorus in numerous biochemical reactions such as arsenite inclines to bind to dithiol groups but do not compete with phosphate. Substituting the less stable As (V) anion to more stable phosphorus anion in phosphate results in quick hydrolysis and loss of high energy phosphate bonds in molecules like ATP which halts the mitochondrial respiration (Klein et al. 2007).

- Specific binding of arsenite to thiol grouphaving hormone receptors blocks the binding of steroids (Kaltreider et al. 2001; Lopez et al. 1990). It is assumed that arsenic's capability to bind and inhibit insulin receptor may lead to diabetogenic effects (Klein et al. 2007).

Carcinogenesis induced by arsenic is seen to have different mechanisms in varying types of tissues. The modes of arsenic carcinogenesis are genotoxic which involve of gene amplification, chromosomal abnormalities and oxidative stress vs. non- 
genotoxic like altered enhanced cell proliferation, altered growth factors, DNA repair and promotion of carcinogenesis (Kitchin 2001). It is observed in studies for genotoxicity, that arsenic obstructs DNA repair, induce sister-chromatid exchanges, chromosomal aberrations, and micronuclei formation (Barrett et al. 1989; Hartmann and Speit 1994; Jha et al. 1992; Vega et al. 1995; Wang et al. 1996). They have also been considered as comutagens and promoters for a range of toxic agents (Huang and Lee 1998; Tchounwou et al. 2003).

Arsenic does not react with the DNA or cause mutations in genes directly. Thus it is also termed as non-clastogenic. However, it causes chromosomal damage and gene amplification at lower doses and increases mutagenesis of other agents by inhibiting DNA repair mechanism. Arsenite interferes with the regulators of DNA repair instead of the repair enzymes as DNA repair enzymes are not sensitive to arsenite inhibition (Kaltreider et al. 2001). Arsenite do not prevent spindle fiber formation, in its place, it accelerates the microtubule polymerization and disrupts the spindle apparatus. It is observed in rat liver epithelial cell line TRL 1215 that arsenite-induced malignant transformation was linked to decreased DNA methyltransferase process, global DNA hypomethylation and activation (overexpression) of the c-myc, a proto-onco gene leading to abnormal gene expression suggesting the carcinogen nature of arsenite (Zhao et al. 1997). Aneuploidy is also one of the results of arsenic toxicity. On human lung A549 carcinoma cells, contrasting results of DNA methylation were seen which increases $\mathrm{CpG}$ methylation in p53 promoter which blocks p53 gene transcription (Mass and Wang 1997). The p53 gene plays significant role in controlling DNA repair, apoptosis and cell cycle control as it is a crucial tumor- suppressor gene (Abernathy et al. 1999).

\subsection{Prenatal arsenic exposure and health effects}

Prenatal and early-life exposure to inorganic arsenic and subsequent health effects represents a global health issue yet is one that is understudied. Inorganic arsenic has toxic effects on the developing fetus in which even fairly modest levels have been associated with detrimental birth effects. Such consequences of exposure comprise of decreased birth weight, decreased chest and head circumferences (Tofail et al. 2009) along with higher risk of infection in infants (Farzan et al. 2011; Rahman et al.). Retrospective cohort investigations have emphasized that in addition to the immediate health effects, early-life exposure to inorganic arsenic is linked to adult diseases including both cancer and non-cancer endpoints (Dauphine et al. 2001; Naujokas et al. 2013)

Parental origin of adult onset diseases is an emerging hypothesis with strong epidemiological data to support it. However, a mechanism pertinent to control of these disease outcomes is still being explored and is a thriving area of research. Aberrant methylation following prenatal arsenic exposure is a widely accepted phenomenon. Recent studies of in utero arsenic exposure have suggested that methylation alterations take place in umbilical cord blood leucocytes of infants (Cardenas et al., 2015; Kile et al. 2014; Koestler et al. 2013). Population studies also reveal the correlation of arsenic exposure and metabolic disorders in adults (Rahman et al. 1999b). There are, however, evidences that support the prenatal origins of various risk factors (including obesity) (Kim et al. 2011; Martinez et al. 2012b; Slomko et al. 2012) that render an individual exceptionally more susceptible towards metabolic syndromes. Many workers have linked prenatal arsenic exposure and the ensuing aberrant methylation to increased risk of cancer in adulthood (Bailey and Fry 2014; Laine et al. 2014; Steinmaus et al. 2014) but the non-cancer endpoints for the exposed individuals are ill explored.

Over 100 million people worldwide, including pregnant women and their unborn children, are exposed to levels of inorganic arsenic (inorganic arsenic) in their drinking water that exceed the World Health Organization's recommended limit 10 $\mu \mathrm{g}$ As/l and are considered detrimental to human health (Uddin and Huda 2011); WHO, 2006). Longterm exposure to inorganic arsenic is associated with the development of diverse chronic health 
conditions in adults including neurological effects, peripheral vascular disease, diabetes mellitus, cardiovascular disease and cancers in several organs including the liver, lungs, skin, urinary bladder and prostate (Gibb et al. 2010; Rahman et al. 2009) . Exposure to high levels of inorganic arsenic during pregnancy is also associated with significant risks to fetal and maternal health along with increased rates of preterm birth, spontaneous abortion, stillbirth, decreased size at birth and decreased birth weight (Vahter 2009). In addition, prenatal and/or early childhood exposure to inorganic arsenic is associated with delayed health effects, together with increased rates of mortality in young adults for both noncancerous diseases and cancers (Farzan et al. 2013). Previous studies have shown that newborns exposed to inorganic arsenic in utero have amplified level of expression of pro inflammatory genes at both the transcriptional level and protein level in umbilical cord blood. There is also substantial evidence that in utero inorganic arsenic exposure can act as an immunosuppressant which is related to increased mortality and morbidity and decreased thymic index in infants (Raqib et al. 2009; Rahman et al. 2010; Hamadani et al. 2010). Altogether it is suggested that in in utero inorganic arsenic exposure, it acts as an immunomodulatory agent (Bailey et al. 2014; Raqib et al. 2009).

The multi-stage chemical carcinogenesis in mouse skin model is the best way to represent in vivo studies both sequential and stepwise tumor development. In this model, initiation is induced by the single dose of a carcinogen like, 7,12dimethylbenz[a]-anthracene (DMBA) followed by the doses of a tumor promoting agent like phorbol ester, 12-Otetradecanoylphorbol- 13-acetate (TPA), which is applied repeatedly. During the initiation step, mutations occur in the epidermal keratinocytes genes due to chemical mutagen exposure. Generally DMBA is applied topically and its effect is irreversible but the visible tumors appear only after the application of a promoter. The primary target gene for the mutation in the initiation stage is Hras1 gene by inducing a transversion in codon $61, \mathrm{~A} \rightarrow \mathrm{T}$
(182) and the primary target at cellular level are the keratinocyte stem cells.

The mutated cells population is expanded clonally by the application of a promoting chemical agent or by wounding. This results in a sustained epidermal hyperplasia demonstrated by the increase in the nucleated cell population and the thickness of the epidermis. The concluding effect of the experiment is the development of papillomas which are outgrowths of the skin. Papilloma comprise of a stromal core bounded by hyperplastic epidermis.

Various promoting agents are structurally and mechanistically diverse in their mode of action. Increased epidermal thickness, increased DNA synthesis, basal keratinocytes proliferation and infiltration of inflammatory cell are the immediate markers for tumor promotion (Abel et al. 2009).

\section{References}

1. Abel, E. L., et al. (2009). Multi-stage chemical carcinogenesis in mouse skin: Fundamentals and applications. Nat. Protoc. 4, 1350-1362.

2. Abernathy, C. O., Liu, Y. P., Longfellow, D., Aposhian, H. V., Beck, B., Fowler, B., Goyer, R., Menzer, R., Rossman, T., Thompson, C., and Waalkes, M. (1999). Arsenic: health effects, mechanisms of actions, and research issues. Environmental health perspectives 107, 593-7.

3. Ahmad, S. A., Sayed, M. H., Barua, S., Khan, M. H., Faruquee, M. H., Jalil, A., Hadi, S. A., and Talukder, H. K. (2001). Arsenic in drinking water and pregnancy outcomes. Environmental health perspectives 109, 629-31.

4. Albores, A., Cebrian, M. E., Garcia-Vargas, G. G., Connelly, J. C., Price, S. C., Hinton, R. H., Bach, P. H., and Bridges, J. W. (1996). Enhanced arsenite-induced hepatic morphological and biochemical changes in phenobarbital-pretreated rats. Toxicologic pathology 24, 172-80.

5. Aposhian, H. V., Zakharyan, R. A., Avram, M. D., Sampayo-Reyes, A., and Wollenberg, 
M. L. (2004). A review of the enzymology of arsenic metabolism and a new potential role of hydrogen peroxide in the detoxication of the trivalent arsenic species. Toxicology and applied pharmacology 198, 327-35.

6. [ATSDR] Agency for Toxic Substances and Disease Registry. 2007. Toxicological profile for arsenic. Draft for Public Comment. Atlanta GA [updated 2007 August; accessed 2008 January 14]. Available from: http://www.atsdr.cdc.gov/toxprofiles/tp2.html.

7. Bailey, K. A., and Fry, R. C. (2014). Arsenic-Associated Changes to the Epigenome: What Are the Functional Consequences? Curr Environ Health Rep 1, 22-34.

8. Bailey, K. A., Laine, J., Rager, J. E., Sebastian, E., Olshan, A., Smeester, L., Drobna, Z., Styblo, M., Rubio-Andrade, M., Garcia-Vargas, G., and Fry, R. C. (2014). Prenatal arsenic exposure and shifts in the newborn proteome: interindividual differences in tumor necrosis factor (TNF)responsive signaling. ToxicolSci139,328-37.

9. Barrett, J. C., Lamb, P. W., Wang, T. C., and Lee, T. C. (1989). Mechanisms of arsenicinduced cell transformation. Biological trace element research 21, 421-9.

10. Buchet, J. P., Lauwerys, R., and Roels, H. (1981). Comparison of the urinary excretion of arsenic metabolites after a single oral dose of sodium arsenite, monomethylarsonate, or dimethylarsinate in man. International archives of occupational and environmental health 48, 71-9.

11. Caldwell, K. L., Jones, R. L., Verdon, C. P., Jarrett, J. M., Caudill, S. P., and Osterloh, J. D. (2009). Levels of urinary total and speciated arsenic in the US population: National Health and Nutrition Examination Survey 2003-2004. Journal of exposure science \& environmental epidemiology 19 , 59-68.
12. Cardenas, A., Koestler, D. C., Houseman, E. A., Jackson, B. P., Kile, M. L., Karagas, M. R., and Marsit, C. J. Differential DNA methylation in umbilical cord blood of infants exposed to mercury and arsenic in utero. Epigenetics 10, 508-15.

13. Cardenas, A., Koestler, D. C., Houseman, E. A., Jackson, B. P., Kile, M. L., Karagas, M. R., and Marsit, C. J. (2015). Differential DNA methylation in umbilical cord blood of infants exposed to mercury and arsenic in utero. Epigenetics 10, 508-15.

14. Chan, T. Y. (1994). The prevalence use and harmful potential of some Chinese herbal medicines in babies and children. Veterinary and human toxicology 36, 238-40.

15. Chung, J. S., Kalman, D. A., Moore, L. E., Kosnett, M. J., Arroyo, A. P., Beeris, M., Mazumder, D. N., Hernandez, A. L., and Smith, A. H. (2002). Family correlations of arsenic methylation patterns in children and parents exposed to high concentrations of arsenic in drinking water. Environmental health perspectives 110, 729-33.

16. Cronican, A. A., Fitz, N. F., Carter, A., Saleem, M., Shiva, S., Barchowsky, A., Koldamova, R., Schug, J., and Lefterov, I. (2013). Genome-wide alteration of histone $\mathrm{H} 3 \mathrm{~K} 9$ acetylation pattern in mouse offspring prenatally exposed to arsenic. PloS one 8, e53478.

17. Datta, D. V. (1976). Letter: Arsenic and non-cirrhotic portal hypertension. Lancet (London, England) 1, 433.

18. Dauphine, D. C., Ferreccio, C., Guntur, S., Yuan, Y., Hammond, S. K., Balmes, J., Smith, A. H., and Steinmaus, C. (2001). Lung function in adults following in utero and childhood exposure to arsenic in drinking water: preliminary findings. Int Arch Occup Environ Health 84, 591-600.

19. Farzan, S. F., Karagas, M. R., and Chen, Y. (2013). In utero and early life arsenic exposure in relation to long-term health and 
disease. Toxicology and applied pharmacology 272, 384-90.

20. Farzan, S. F., Korrick, S., Li, Z., Enelow, R., Gandolfi, A. J., Madan, J., Nadeau, K., and Karagas, M. R. (2011). In utero arsenic exposure and infant infection in a United States cohort: a prospective study. Environmental research 126, 24-30.

21. Fry, R. C., Navasumrit, P., Valiathan, C., Svensson, J. P., Hogan, B. J., Luo, M., Bhattacharya, S., Kandjanapa, K., Soontararuks, S., Nookabkaew, S., Mahidol, C., Ruchirawat, M., and Samson, L. D. (2007). Activation of inflammation/NFkappaB signaling in infants born to arsenicexposed mothers. PLoS genetics 3, e207.

22. Garvey, G. J., Hahn, G., Lee, R. V., and Harbison, R. D. (2001). Heavy metal hazards of Asian traditional remedies. International journal of environmental health research 11, 63-71.

23. Gibb, H., Haver, C., Gaylor, D., Ramasamy, S., Lee, J. S., Lobdell, D., Wade, T., Chen, C., White, P., and Sams, R. (2010). Utility of recent studies to assess the National Research Council 2001 estimates of cancer risk from ingested arsenic. Environmental health perspectives 119, 284-90.

24. Giberson, A., Vaziri, N. D., Mirahamadi, K., and Rosen, S. M. (1976). Hemodialysis of acute arsenic intoxication with transient renal failure. Archives of internal medicine 136, 1303-4.

25. Hall, M., Gamble, M., Slavkovich, V., Liu, X., Levy, D., Cheng, Z., van Geen, A., Yunus, M., Rahman, M., Pilsner, J. R., and Graziano, J. (2007). Determinants of arsenic metabolism: blood arsenic metabolites, plasma folate, cobalamin, and homocysteine concentrations in maternal-newborn pairs. Environmental health perspectives 115, 1503-9.

26. Hamadani, J. D., Grantham-McGregor, S. M., Tofail, F., Nermell, B., Fangstrom, B., Huda, S. N., Yesmin, S., Rahman, M., Vera-
Hernandez, M., Arifeen, S. E., and Vahter, M. (2010). Pre- and postnatal arsenic exposure and child development at 18 months of age: a cohort study in rural Bangladesh. International journal of epidemiology 39, 1206-16.

27. Hartmann, A., and Speit, G. (1994). Comparative investigations of the genotoxic effects of metals in the single cells gel (SCG) assay and the sister chromatid exchange (SCE) test. Environmental and molecular mutagenesis 23, 299-305.

28. Herrera, B. M., Keildson, S., and Lindgren, C. M. (2011). Genetics and epigenetics of obesity. Maturitas 69, 41-9.

29. Hopenhayn-Rich, C., Browning, S. R., Hertz-Picciotto, I., Ferreccio, C., Peralta, C., and Gibb, H. (2000). Chronic arsenic exposure and risk of infant mortality in two areas of Chile. Environmental health perspectives 108, 667-73.

30. Hopenhayn, C., Ferreccio, C., Browning, S. R., Huang, B., Peralta, C., Gibb, H., and Hertz-Picciotto, I. (2003). Arsenic exposure from drinking water and birth weight. Epidemiology 14, 593-602.

31. Hu, J., Fang, J., Dong, Y., Chen, S. J., and Chen, Z. (2005). Arsenic in cancer therapy. Anti-cancer drugs 16, 119-27.

32. Huang, S. C., and Lee, T. C. (1998). Arsenite inhibits mitotic division and perturbs spindle dynamics in HeLa S3 cells. Carcinogenesis 19, 889-96.

33. IARC (2004). Some drinking-water disinfectants and contaminants, including arsenic. IARC monographs on the evaluation of carcinogenic risks to humans / World Health Organization, International Agency for Research on Cancer 84, 1-477.

34. Jha, A. N., Noditi, M., Nilsson, R., and Natarajan, A. T. (1992). Genotoxic effects of sodium arsenite on human cells. Mutation research 284, 215-21.

35. Kaltreider, R. C., Davis, A. M., Lariviere, J. P., and Hamilton, J. W. (2001). Arsenic 
alters the function of the glucocorticoid receptor as a transcription factor. Environmental health perspectives 109, 245-51.

36. Kerr, H. D., and Saryan, L. A. (1986). Arsenic content of homeopathic medicines. Journal of toxicology 24, 451-9.

37. Kile, M. L., Houseman, E. A., Baccarelli, A. A., Quamruzzaman, Q., Rahman, M., Mostofa, G., Cardenas, A., Wright, R. O., and Christiani, D. C. (2014). Effect of prenatal arsenic exposure on DNA methylation and leukocyte subpopulations in cord blood. Epigenetics 9, 774-82.

38. Kim, E. J., Herrera, J. E., Huggins, D., Braam, J., and Koshowski, S. (2011). Effect of $\mathrm{pH}$ on the concentrations of lead and trace contaminants in drinking water: a combined batch, pipe loop and sentinel home study. Water Res 45, 2763-74.

39. Kitchin, K. T. (2001). Recent advances in arsenic carcinogenesis: modes of action, animal model systems, and methylated arsenic metabolites. Toxicology and applied pharmacology 172, 249-61.

40. Klein, C. B., Leszczynska, J., Hickey, C., and Rossman, T. G. (2007). Further evidence against a direct genotoxic mode of action for arsenic-induced cancer. Toxicology and applied pharmacology 222, 289-97.

41. Koestler, D. C., Avissar-Whiting, M., Houseman, E. A., Karagas, M. R., and Marsit, C. J. (2013). Differential DNA methylation in umbilical cord blood of infants exposed to low levels of arsenic in utero. Environ Health Perspect 121, 971-7.

42. Kwok, R. K., Kaufmann, R. B., and Jakariya, M. (2006). Arsenic in drinkingwater and reproductive health outcomes: a study of participants in the Bangladesh Integrated Nutrition Programme. J Health PopulNutr 24, 190-205.

43. Kyle, R. A., and Pease, G. L. (1965). Hematologic Aspects of Arsenic
Intoxication. The New England journal of medicine 273, 18-23.

44. Lai, M. S., Hsueh, Y. M., Chen, C. J., Shyu, M. P., Chen, S. Y., Kuo, T. L., Wu, M. M., and Tai, T. Y. (1994). Ingested inorganic arsenic and prevalence of diabetes mellitus. American journal of epidemiology 139, 48492.

45. Laine, J. E., Bailey, K. A., Rubio-Andrade, M., Olshan, A. F., Smeester, L., Drobna, Z., Herring, A. H., Styblo, M., Garcia-Vargas, G. G., and Fry, R. C. (2014). Maternal arsenic exposure, arsenic methylation efficiency, and birth outcomes in the Biomarkers of Exposure to ARsenic (BEAR) pregnancy cohort in Mexico. Environ Health Perspect 123, 186-92.

46. Lansdown, A. B. (1995). Physiological and toxicological changes in the skin resulting from the action and interaction of metal ions. Critical reviews in toxicology 25, 397-462.

47. Lopez, S., Miyashita, Y., and Simons, S. S., Jr. (1990). Structurally based, selective interaction of arsenite with steroid receptors. The Journal of biological chemistry 265, 16039-42.

48. Lugo, G., Cassady, G., and Palmisano, P. (1969). Acute maternal arsenic intoxication with neonatal death. American journal of diseases of children (1960) 117, 328-30.

49. Marafante, E., Vahter, M., Norin, H., Envall, J., Sandstrom, M., Christakopoulos, A., and Ryhage, R. (1987). Biotransformation of dimethylarsinic acid in mouse, hamster and man. J ApplToxicol 7, 111-7.

50. Martinez, J. A., Cordero, P., Campion, J., and Milagro, F. I. (2012a). Interplay of early-life nutritional programming on obesity, inflammation and epigenetic outcomes. The Proceedings of the Nutrition Society 71, 276-83.

51. Martinez, V. D., Vucic, E. A., Lam, S., and Lam, W. L. (2012b). Arsenic and lung cancer in never-smokers: lessons from Chile. Am J RespirCrit Care Med 185, 1131-2. 
52. Mass, M. J., and Wang, L. (1997). Arsenic alters cytosine methylation patterns of the promoter of the tumor suppressor gene p53 in human lung cells: a model for a mechanism of carcinogenesis. Mutation research 386, 263-77.

53. Miller, W. H., Jr., Schipper, H. M., Lee, J. S., Singer, J., and Waxman, S. (2002). Mechanisms of action of arsenic trioxide. Cancer research 62, 3893-903.

54. Murunga E, Zawada E. (2007). "Environmental and occupational causes of toxic injury to the kidneys and urinary tract." In: Rom $\mathrm{W}$ and Markowitz $\mathrm{S}$ eds. Environmental and occupational medicine, 4th ed. Hagerstown, MD: Lippincott Williams \& Wilkins. p. 810.

55. NAS (1977). National Academy of Sciences.

56. Naujokas, M. F., Anderson, B., Ahsan, H., Aposhian, H. V., Graziano, J. H., Thompson, C., and Suk, W. A. (2013). The broad scope of health effects from chronic arsenic exposure: update on a worldwide public health problem. Environ Health Perspect 121, 295-302.

57. Nordstrom, S., Beckman, L., and Nordenson, I. (1979). Occupational and environmental risks in and around a smelter in northern Sweden. V. Spontaneous abortion among female employees and decreased birth weight in their offspring. Hereditas 90, 291-6.

58. NRC (1986). Drinking Water and Health. National Academies Press (US).

59. NRC (2001). Arsenic in drinking water. National Research Council.

60. Perez, D. S., Armstrong-Lea, L., Fox, M. H., Yang, R. S., and Campain, J. A. (2003). Arsenic and benzo[a]pyrene differentially alter the capacity for differentiation and growth properties of primary human epidermal keratinocytes. ToxicolSci 76, 280-90.

61. Popper, H., Thomas, L. B., Telles, N. C., Falk, H., and Selikoff, I. J. (1978). Development of hepatic angiosarcoma in man induced by vinyl chloride, thorotrast, and arsenic. Comparison with cases of unknown etiology. The American journal of pathology 92, 349-76.

62. Rahman, A., Vahter, M., Ekstrom, E. C., and Persson, L. A. Arsenic exposure in pregnancy increases the risk of lower respiratory tract infection and diarrhea during infancy in Bangladesh. Environmental health perspectives 119, 719-24.

63. Rahman, M., Sohel, N., Yunus, M., Chowdhury, M. E., Hore, S. K., Zaman, K., Bhuiya, A., and Streatfield, P. K. (2010). Increased childhood mortality and arsenic in drinking water in Matlab, Bangladesh: a population-based cohort study. PloS one 8, e55014.

64. Rahman, M., Tondel, M., Ahmad, S. A., and Axelson, O. (1998). Diabetes mellitus associated with arsenic exposure in Bangladesh. American journal of epidemiology 148, 198-203.

65. Rahman, M., Tondel, M., Ahmad, S. A., Chowdhury, I. A., Faruquee, M. H., and Axelson, O. (1999a). Hypertension and arsenic exposure in Bangladesh. Hypertension 33, 74-8.

66. Rahman, M., Tondel, M., Chowdhury, I. A., and Axelson, O. (1999b). Relations between exposure to arsenic, skin lesions, and glucosuria. Occup Environ Med 56, 277-81.

67. Rahman, M. M., Ng, J. C., and Naidu, R. (2009). Chronic exposure of arsenic via drinking water and its adverse health impacts on humans. Environmental geochemistry and health 31 Suppl 1, 189-200.

68. Raqib, R., Ahmed, S., Sultana, R., Wagatsuma, Y., Mondal, D., Hoque, A. M., Nermell, B., Yunus, M., Roy, S., Persson, L. A., Arifeen, S. E., Moore, S., and Vahter, M. (2009). Effects of in utero arsenic exposure on child immunity and morbidity in rural Bangladesh. Toxicology letters 185, 197202. 
69. Rose, M., Lewis, J., Langford, N., Baxter, M., Origgi, S., Barber, M., MacBain, H., and Thomas, K. (2007). Arsenic in seaweed-forms, concentration and dietary exposure. Food ChemToxicol 45, 1263-7.

70. Selzer, P. M., and Ancel, M. A. (1983). Chronic arsenic poisoning masquerading as pernicious anemia. The Western journal of medicine 139, 219-20.

71. Shalat, S. L., Walker, D. B., and Finnell, R. H. (1996). Role of arsenic as a reproductive toxin with particular attention to neural tube defects. Journal of toxicology and environmental health 48, 253-72.

72. Slomko, H., Heo, H. J., and Einstein, F. H. (2012). Minireview: Epigenetics of obesity and diabetes in humans. Endocrinology 153, 1025-30.

73. Steinmaus, C., Ferreccio, C., Acevedo, J., Yuan, Y., Liaw, J., Duran, V., Cuevas, S., Garcia, J., Meza, R., Valdes, R., Valdes, G., Benitez, H., VanderLinde, V., Villagra, V., Cantor, K. P., Moore, L. E., Perez, S. G., Steinmaus, S., and Smith, A. H. (2014). Increased lung and bladder cancer incidence in adults after in utero and early-life arsenic exposure. Cancer Epidemiol Biomarkers Prev 23, 1529-38.

74. Stockert, E., Boyse, E. A., Obata, Y., Ikeda, H., Sarkar, N. H., and Hoffman, H. A. (1975). New mutant and congenic mouse stocks expressing the murine leukemia virus-associated thymocyte surface antigen GIX. The Journal of experimental medicine $142,512-7$.

75. Tchounwou, P. B., Patlolla, A. K., and Centeno, J. A. (2003). Carcinogenic and systemic health effects associated with arsenic exposure--a critical review. Toxicologic pathology 31, 575-88.

76. Tofail, F., Vahter, M., Hamadani, J. D., Nermell, B., Huda, S. N., Yunus, M., Rahman, M., and Grantham-McGregor, S. M. (2009). Effect of arsenic exposure during pregnancy on infant development at 7 months in rural Matlab, Bangladesh. Environmental health perspectives 117, 28893.

77. Uddin, R., and Huda, N. H. (2011). Arsenic poisoning in bangladesh. Oman medical journal 26, 207.

78. Vahter, M. (2002). Mechanisms of arsenic biotransformation. Toxicology 181-182, 211-7.

79. Vahter, M. (2009). Effects of arsenic on maternal and fetal health. Annual review of nutrition 29, 381-99.

80. Vahter, M., Marafante, E., and Dencker, L. (1983). Metabolism of arsenobetaine in mice, rats and rabbits. The Science of the total environment 30, 197-211.

81. Vega, L., Gonsebatt, M. E., and OstroskyWegman, P. (1995). Aneugenic effect of sodium arsenite on human lymphocytes in vitro: an individual susceptibility effect detected. Mutation research 334, 365-73.

82. von Ehrenstein, O. S., GuhaMazumder, D. N., Hira-Smith, M., Ghosh, N., Yuan, Y., Windham, G., Ghosh, A., Haque, R., Lahiri, S., Kalman, D., Das, S., and Smith, A. H. (2006). Pregnancy outcomes, infant mortality, and arsenic in drinking water in West Bengal, India. American journal of epidemiology 163, 662-9.

83. Waalkes, M. P., Liu, J., Ward, J. M., and Diwan, B. A. (2004). Animal models for arsenic carcinogenesis: inorganic arsenic is a transplacental carcinogen in mice. Toxicology and applied pharmacology 198, 377-84.

84. Wang, Z., Dey, S., Rosen, B. P., and Rossman, T. G. (1996). Efflux-mediated resistance to arsenicals in arsenic-resistant and -hypersensitive Chinese hamster cells. Toxicology and applied pharmacology 137, 112-9.

85. [WHO] World Health Organization (WHO). Arsenic and arsenic compounds, 2nd edn. Environmental Health Criteria 224. Geneva $\mathrm{CH}$ [updated 2001; accessed 2016 july 2]. 
Available from: http://www.inchem.org/documents/ehc/ehc/ehc224.htm

86. Winski, S. L., and Carter, D. E. (1995). Interactions of rat red blood cell sulfhydryls with arsenate and arsenite. Journal of toxicology and environmental health 46, 379-97.

87. Yang, C. Y., Chang, C. C., Tsai, S. S., Chuang, H. Y., Ho, C. K., and Wu, T. N. (2003). Arsenic in drinking water and adverse pregnancy outcome in an arseniasisendemic area in northeastern Taiwan. Environ Res 91, 29-34.

88. Yip L, Dart R. 2001. Arsenic. In: Sullivan J and Kreiger G, eds. Clinical environmental health and toxic exposures, Second Edition. Philadelphia, PA: Lippincott Williams \& Wilkins. p. 858-865.

89. Yoshida, T., Yamauchi, H., and Fan Sun, G. (2004). Chronic health effects in people exposed to arsenic via the drinking water: dose-response relationships in review. Toxicology and applied pharmacology 198, 243-52.

90. Zaldivar, R., Prunes, L., and Ghai, G. L. (1981). Arsenic dose in patients with cutaneous carcinomata and hepatic hemangio-endothelioma after environmental and occupational exposure. Archives of toxicology 47, 145-54.

91. Zhao, C. Q., Young, M. R., Diwan, B. A., Coogan, T. P., and Waalkes, M. P. (1997). Association of arsenic-induced malignant transformation with DNA hypomethylation and aberrant gene expression. Proceedings of the National Academy of Sciences of the United States of America 94, 10907-12. 